\title{
Penyuluhan Kesehatan Pola Hidup Sehat Secara Daring menggunakan Zoom dan Youtube Sebagai Media Ajar pada Masa Pandemi COVID-19
}

\author{
Murtiningsih \\ Program Studi Profesi Ners, STIKes Jayakarta \\ Jln. Babarsari, Tambak Bayan, Depok, Sleman, Yogyakarta, Indonesia \\ Email: murtiningsihkadun@gmail.com
}

\begin{abstract}
Abstrak
Organisasi Kesehatan Dunia WHO (world health Organization) telah menetapkan COVID-19 sebagai pandemi. Pada tanggal 2 Maret 2020 Presiden Republik Indonesia mengumumkan kasus pertama positif COVID-19. Setiap orang perlu menjaga kesehatan dan menghindari faktor yang dapat menyebabkan penularan penyakit. Pencegahan penularan penyakit tersebut diantaranya adalah dengan menjaga perilaku sehat melalui mencuci tangan, memakai masker dan menjaga jarak. Salah satu upaya untuk mencegah tertularnya COVID-19 adalah dengan meningkatkan imunitas. Melalui pola hidup sehat diharapkan dapat meningkatkan imunitas individu. Salah satu upaya untuk meningkatkan pengetahuan tentang hidup sehat adalah melalui penyuluhan kesehatan. Pada saat pandemi penyuluhan kesehatan dapat dilakukan tanpa berkumpul, tetapi dapat dilakukan secara daring di rumah masing-masing. Media zoom dan youtube merupakan salah satu upaya untuk menyebarkan informasi penyuluhan kesehatan. Kegiatan penyuluhan kesehatan tentang pola hidup sehat telah dilakukan secara daring pada tanggal 19 Mei 2020. Kegiatan tersebut didukung oleh Yayasan Nafa Insan Cendekia. Peserta yang mengikuti penyuluhan kesehatan tersebut melalui Zoom berjumlah 24 orang, diantaranya seorang dari warga negara Malaysia. Selain menggunakan media zoom juga ditayangkan secara live melalui youtube. Kegiatan diawali dengan penyuluhan kesehatan dan tanya jawab. Tayangan ulang dapat dilihat kembali pada link youtube, diharapkan dapat menyebarkan informasi lebih luas lagi tentang pola hidup sehat tersebut. Tayangan youtube tersebut dapat dilihat pada chanel youtube Nafa' Insan Cendekia.
\end{abstract}

Kata Kunci: Penyuluhan, pola hidup sehat, COVID-19, Zoom, Youtube.

\section{Pendahuluan}

Pada tanggal 11 Februari 2020 WHO mengumumkan nama virus baru yaitu Corona Virus Deasease (Covid-19). Virus tersebut menyebar ke berbagai Negara dengan perantaraan pergerakan manusia termasuk Indonesia. Pada tanggal 2 Maret 2020 Presiden Republik Indonesia mengumumkan kasus pertama positif COVID-19 [1].

Berdasarkan penyelidikan epidemiologi, masa inkubasi COVID-19 berkisar antara 1 hingga 14 hari, dan umumnya akan terjadi dalam 3 hingga 7 hari. Demam, kelelahan dan batuk kering dianggap sebagai manifestasi klinis utama. Gejala seperti hidung tersumbat, pilek, pharyngalgia, mialgia dan diare relative jarang terjadi pada kasus yang parah, dispnea dan / atau hipoksemia biasanya terjadi setelah satu minggu setelah onset penyakit, dan yang lebih buruk dapat dengan cepat berkembang menjadi sindrom gangguan pernapasan akut, syok [1].

Perawatan terduga COVID-19 yaitu terapi umum dan terapi pengobatan tradisional yang diarahkan pada peningkatan daya tahan tubuh. Tubuh manusia mempunyai mekanisme pertahanan tubuh untuk menangkal pathogen seperti virus, bakteri, jamur dan parasit. Selain hal tersebut juga yang penting dalam mencegah tertularnya virus COVID-19 melalui perilaku hidup sehat seperti mencuci tangan, memakai masker dan menjaga jarak. 
Tema penyuluhan kesehatan hidup sehat ala Rasulullah. Rasulullah merupakan tauladan untuk hidup sehat. Mengapa Rasulullah semasa hidupnya tidak pernah sakit karena mengamalkan pola hidup yang sehat [2]. Penyuluhan kesehatan semasa pandemi dilakukan secara daring dengan menggunakan media teknologi informasi Zoom dan Youtube. Zoom merupakan salah satu aplikasi yang dapat digunakan dalam pembelajaran secara virtual, dimana pengajaran secara virtual atau video dapat tersampaikan dengan baik [3]. Penyuluhan kesehatan yang diberikan secara daring menggunakan media zoom. Penyuluhan kesehatan juga ditayangkan pada channel youtube untuk lebih memperluas pemberian informasi kepada masyarakat. Pada masa pandemi Covid-19, Youtube merupakan salah satu alternatif sebagai media pembelajaran [4]. Youtube merupakan sebuah situs yang secara khusus menawarkan layanan video sharing. Setiap pengunjung dapat bebas menonton dan mendownload video-video yang diinginkannya [5].

\subsection{Tujuan Kegiatan}

Tujuan dari kegiatan ini adalah untuk meningkatkan pengetahuan tentang pola hidup sehat sebagai upaya meningkatkan imunitas pada saat pandemii Covid 19.

\subsection{Manfaat Kegiatan}

Setelah kegiatan ini dilaksanakan, peserta dapat memahami tentang pola hidup sehat dan dapat mengaplikasikannya.

\section{Realisasi Kegiatan}

\subsection{Bentuk Kegiatan \& Jadwal, Serta Tempat Kegiatan \\ a. Metode Pelaksanaan Kegiatan}

Metode pelaksanaan kegiatan pengabdian terdiri dari Ceramah dan Tanya Jawab melalui zoom dan youtube.

\section{b. Waktu Efektif Pelaksanaan Kegiatan}

Kegiatan Pelaksanaan Pengabdian Kepada Masyarakat ini dilakukan 19 Mei 2020.

\section{c. Tempat Kegiatan}

Kegiatan dilakukan di rumah masing-masing secara daring melalui media zoom dan youtube dengan link: https:/ / www.youtube.com/watch?v=x4SddXe8weI\&t=316s.

\subsection{Hasil Pelaksanaan Pengabdian}

Pelaksanaan kegiatan Pengabdian Kepada Masyarakat melalui media zoom dan youtube berjalan dengan lancer. Peserta yang hadir melalui zoom ada 24 orang, dimana seorang diantaranya adalah Warga Negara Malaysia.

Berikut ini merupakan jalannya penyuluhan kesehatan tentang pola hidup sehat:

a. Persiapan

Sebelum dimulainya acara promosi acara disebarkan melalui media sosial WhatsApp dan facebook. Link zoom dan youtube diberikan kepada peserta yang ingin bergabung untuk mengikuti penyuluhan tersebut. Pada acara tersebut didukung oleh Yayasan Nafa Insan Cendekia. Pembicara acara tersebut yaitu Murtiningsih, M.Kep, Sp.Mat, moderator Asma Taqiya. 


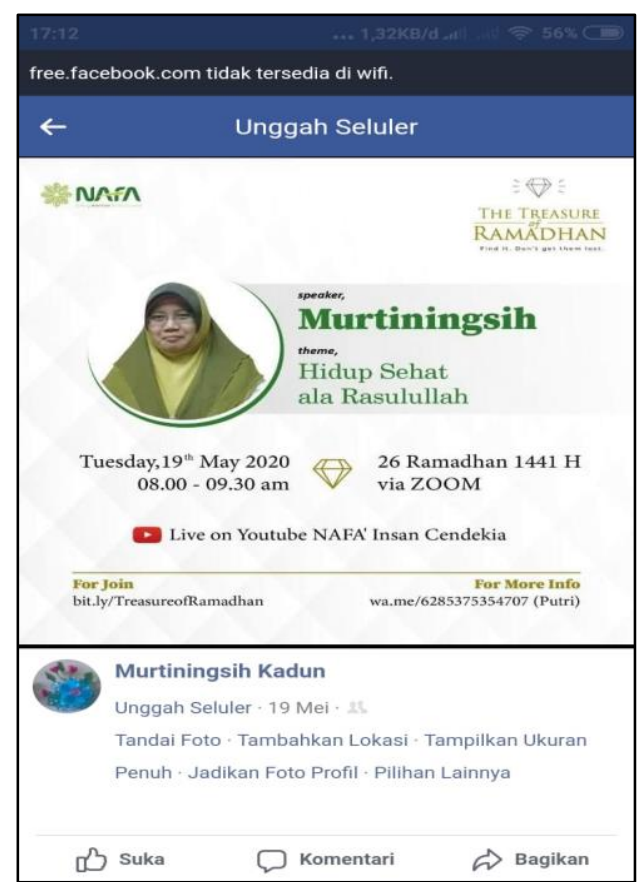

Gambar 1. Poster Sosial Media Sharing

b. Penyuluhan kesehatan Pola hidup sehat

Pembukaan acara dilakukan oleh moderator. Selanjutnya penyuluhan kesehatan pola hidup sehat mengikut tauladan Rasulullah diberikan oleh Murtiningsih, M.Kep, Sp. Mat. Selain dapat dilihat pada channel youtube Nafa'Insan Cendekia, materi tentang pola hidup sehat mengikuti Rasulullah juga dapat di download pada wordpress Murtiningsih, M.Kep, Sp. Mat pada link https://religioushal.wordpress.com/tips-sehat-berkah-rasulullah/

Setelah penyuluhan kesehatan selesai dilanjutkan dengan tanya jawab dan diskusi. Semua pertanyaan telah Diskusi berjalan dengan lancar dan beberapa pertanyaan diajukan. Acara tersebut berlangsung selama 1 jam 37 menit.ijawab.

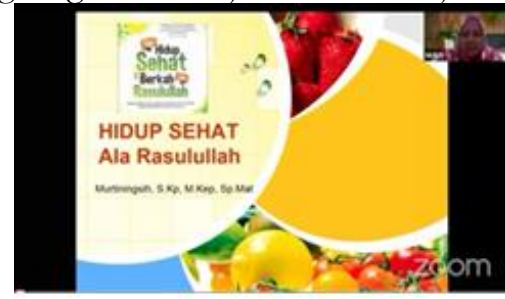

Live Talk \#3: "Hidup Sehat Ala Rasul" bersama Murtiningsih, M.Kep., Sp.Mat $102 \times$ ditonton
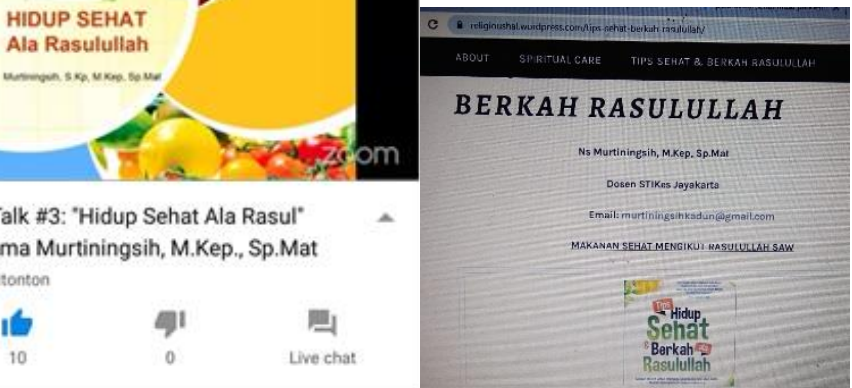

Gambar 2. Link Youtube Live dan Materi

c. Penutup

Acara ditutup oleh moderator dengan memotivasi kepada para peserta untuk dapat mengaplikasi pola hidup sehat yang telah diberikan pada penyuluhan tersebut.

\subsection{Masyarakat Sasaran}

Adapun ruang lingkup utama dari kegiatan pengabdian kepada masyarakat ini adalah untuk memberikan pengetahuan tentang pola hidup sehat pada masyarakat umumnya. 


\section{Daftar Pustaka}

[1] Tim Kerja Kementerian Dalam Negeri. Pedoman Umum Menghadapi Pandemi Covid-19 Bagi Pemerintah Daerah: Pencegahan, Pengendalian, Diagnosis dan Manajemen. https://covid19.kemkes.go.id/downloads/?dl_cat=7\#.X8YGuWUzbIW. Published 2020.

[2] Murtiningsih. Tips sehat dan Berkah Rulullah. https: / / scholar.googleusercontent.com/citations?view_op=export_citations\&user=HiI45q QAAAAJ\&citsig=AMD79ooAAAAAX8t_B9dHmflO-2w5xl1LFikufHOslWVZ\&hl=id.

[3] Yuliani, M., Simarmata, J., Susanti, S.S., Mahawati, E., Sudra, R.I., Dwiyanto, H., Irawan, E., Ardiana, D.P.Y., Muttaqin, M. and Yuniwati, I., 2020. Pembelajaran Daring untuk Pendidikan: Teori dan Penerapan. Yayasan Kita Menulis.

[4] Sari, L., 2020. Upaya Menaikkan Kualitas Pendidikan Dengan Pemanfaatan Youtube Sebagai Media Ajar Pada Masa Pandemi COVID-19. Jurnal Tawadhu, 4(1), pp.1074-1084.

[5] Laksamana Media., 2009. YouTube dan Google Video. Yogyakarta: MediaKom. 